\title{
PERBAIKAN TANAH LEMPUNG LUNAK DENGAN METODE PREFABRICATED VERTICAL DRAIN (PVD)
}

\author{
Rifki Ali ${ }^{1 \Xi}$, Sri Wulandari \\ ${ }^{1,2}$ Universitas Gunadarma, Program Studi Teknik Sipil, Jl. Margonda Raya No. 100, 16424 \\ ${ }^{\circledR}$-mail : ${ }^{1}$ rifqiali999@gmail.com, ${ }^{2}$ sri_wulandari@staffsite.gunadarma.ac.id
}

\begin{abstract}
In Kapal Betung toll road project (Kayu Agung - Palembang - Betung) in South Sumatra, the subsoil consists of soft clay soil. The long-term problem of a slowdown in consolidation is a problem that needs to be addressed in this type of soil. One of soil improvement methods to accelerated consolidation process for increasing the soil strength process is the application of Prefabricated Vertical Drain (PVD). PVD method must be accompanied by a initial load to increase the pore water pressure, so that the consolidation can proceed. Soil is a material commonly used for a initial load, not only soil but also vacuum pressure can also be used as a initial load. Based on the analysis, the value of settlement consolidation in this project was between 0,37 and 1,32 meters with a variety of natural consolidation periods ranging from 16,66 to 35,75 years. When using $P V D$ with a $1 \mathrm{~m}$ distance and a reference value of ch/cv 1,5, the time of consolidation is 4 to 10 weeks. It can be concluded that PVD can accelerate the consolidation period. When we use PVD combined with loads in the form of landfill and vacuum pressure, PVD precharge construction time is 14 to 126 days with high of initial load soil precharge levels 7,61 to 9,86 meters, while the construction time for vacuum PVD method is 6 to 14 days with a precharge pile height of 4,67 to 6,92 meters. From the results of the analysis, it can be concluded that the vacuum method has advantages that it doesn't take a long time to make a slopes contruction as a initial load. Vacuum method also requires less soil as a initial load needed than the preload method. It can be happened because of the vacuum pressure can replace \pm 4 meters of landfill.
\end{abstract}

Keywords: Consolidation, Prevabricated Vertical Drain (PVD), Preloading, Vakum, Safety Factor

\begin{abstract}
Abstrak
Pada Proyek Jalan Tol Kapal Betung (Kayu Agung - Palembang - Betung) Sumatera Selatan, tanah dasar terdiri dari tanah lempung lunak. Permasalahan penurunan konsolidasi yang cukup besar dalam jangka waktu yang lama merupakan permasalahan yang harus diselesaikan pada tanah jenis ini. Salah satu metode yang dapat diaplikasikan untuk menanggulangi permasalahan ini adalah menggunakan prefabricated vertical drain (PVD) untuk mempercepat proses konsolidasi. Aplikasi PVD harus disertai dengan pemberian beban awal (prabeban) untuk meningkatkan tegangan air pori tanah sehingga proses konsolidasi dapat berjalan. Timbunan dari tanah merupakan material yang umum digunakan, selain tanah dapat juga digunakan beban yang berupa tekanan vakum. Berdasarkan analisa, besar penurunan konsolidasi pada proyek ini berkisar antara 0,37 - 1,32 m dengan waktu konsolidasi alami yang beragam yaitu antara 16,46 - 35,75 tahun. Sementara itu, jika menggunakan $P V D$ dengan jarak antar PVD $1 \mathrm{~m}$ dan nilai perbandingan $c_{h} / c_{v} 1,5$ diperoleh waktu konsolidasi berkisar antara 4 - 10 minggu. Maka dapat disimpulkan bahwa PVD dapat mempercepat waktu konsolidasi. PVD dikombinasikan dengan beban berupa tanah timbunan maupun tekanan vakum. Waktu Konstruksi PVD Preloading yaitu 14 - 126 hari dangan tinggi timbunan Preloading 7,61 - 9,86 m, sedangkan waktu konstruksi PVD Vakum yaitu 6 - 14 hari dengan tinggi timbunan Preloading 4,67 - 6,92 m. Dari hasil analisa yang telah dilakukan dapat disimpulkan bahwa metode vakum memiliki keunggulan dimana pada metode ini tidak membutuhkan waktu konstruksi timbunan yang lama. Selain itu dengan menggunakan metode vakum, volume tanah timbunan yang diperlukan lebih sedikit jika dibandingkan dengan metode Preloading. Hal ini dikarenakan tekanan vakum dapat menggantikan $\pm 4 m$ tanah timbunan.
\end{abstract}

Kata kunci: Konsolidasi, Prevabricated Vertical Drain (PVD), Preloading, Vacuum, Faktor Keamanan

197 


\section{Pendahuluan}

Penurunan yang besar dan periode konsolidasi yang panjang akan terjadi bila jalan yang di konstruksikan di atas tanah dasar yang lunak tidak diperkuat sehingga dapat mengakibatkan kerusakan pada struktur perkerasan jalan [2]. Hal ini disebabkan karena tanah lunak mempunyai karakteristik yaitu kompresibilitas yang tinggi dengan kekuatan geser yang kecil, tanah lunak mempunyai kekuatan geser kurang dari $25 \mathrm{kPa}$. Oleh karena itu, penimbunan yang dilaksanakan diatas tanah lunak akan mengalami kegagalan geser dan penurunan yang berlebihan. Ini diakibatkan pada saat pemberian beban pada tanah akan mengakibatkan penurunan seketika diikuti oleh proses konsolidasi. Pada umumnya penurunan konsolidasi membutuhkan waktu yang dapat menunda pekerjaan konstruksi dengan cukup lama [5]. Terdapat berbagai metode perbaikan tanah yang umumnya diaplikasikan untuk menanggulangi permasalahan ini, diantaranya adalah menggunakan prefabricated vertical drain (PVD).

PVD adalah pita memanjang dari bahan sintetis yang terdiri dari jaket yang dapat merembeskan air pori ke dalam inti yang bergaris-garis. Inti ini berfungsi sebagai pengumpul air pori dan mengalirkannya keluar ke atas menuju tekanan yang lebih rendah [8].

Aplikasi prefabricated vertical drain (PVD) harus disertai dengan pemberian beban untuk meningkatkan tegangan air pori tanah sehingga proses konsolidasi dapat berjalan. Beban yang digunakan dapat berupa timbunan tanah maupun tekanan pompa vakum.

Pada metoda Preloading dengan PVD (prefabricated vertical drain), perbaikan tanah dilakukan dengan cara meletakkan beban (preload) pada tanah dasar sesuai dengan beban kerja (work load) dan beban konstruksi (construction load) yang direncanakan. Durasi pembebanan dilakukan sampai konsolidasi tanah dasar mencapai derajat konsolidasi yang direncanakan. Apabila derajat konsolidasi tanah dasar telah mencapai pada derajat yang direncanakan maka preload dibongkar dan konstruksi dimulai pelaksanaan-nya [4].

\section{Metode Penelitian}

Tanah dasar dengan konsistensi lunak yang sangat dalam menyebabkan penurunan konsolidasi yang besar dan membutuhkan waktu yang sangat lama. Oleh karena itu, dilakukan upaya untuk mempercepat penurunan konsolidasi yaitu dengan prefabticated vertical drain. Metode ini bertujuan untuk mempercepat terjadinya penurunan konsolidasi, sehingga di atas tanah tersebut dapat segera dilakukan pekerjaan konstruksi [3]. PVD merupakan lembaran pita yang terbuat dari bahan polimer yang dipancangkan ke dalam tanah lunak, di mana kedalaman pemancangan PVD dibatasi hanya sampai $\mathrm{N}_{\mathrm{SPT}}<10$. Terdapat 2 metode yang dapat digunakan untuk mendukung sistem PVD yaitu metode Preloading dan metode vakum. Setelah dilakukan perbaikan tanah lunak dengan PVD, maka tanah dasar akan memiliki daya dukung yang lebih baik karena air pori tanah telah terdrainase dan menghasilkan partikel tanah yang padat. Alur penelitian Konsolidasi Pada Tanah Lempung Lunak terdapat pada Gambar 1. 


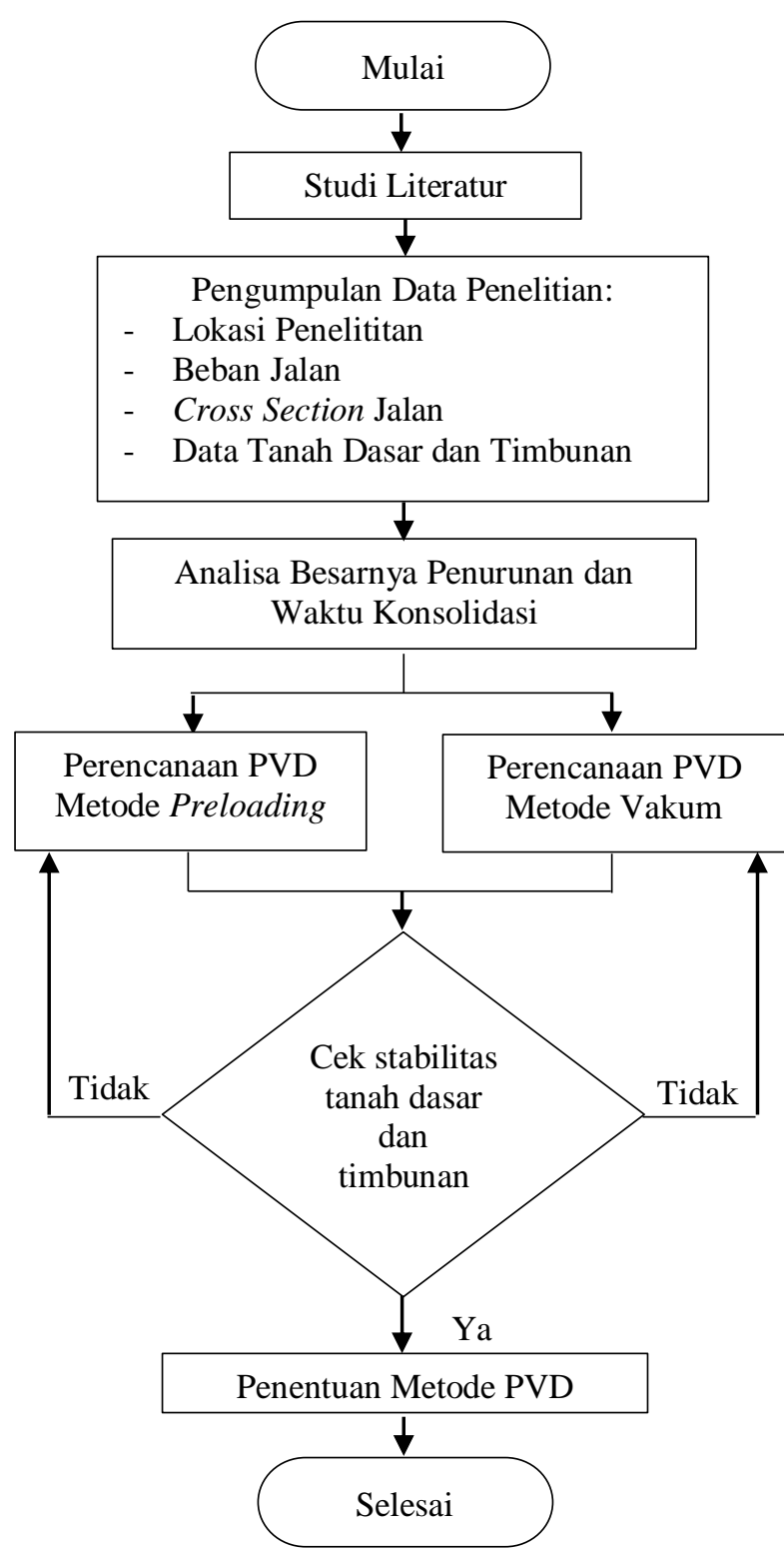

Gambar 1. Analisis Konsolidasi Pada Tanah Lempung Lunak Dengan Menggunakan Metode Prefabricated Vertical Drain (PVD)

\section{Hasil dan Pembahasan}

Lokasi penelitiaan merupakan Jalan Tol Kapal Betung (Kayu Agung - Palembang Betung), Palembang, Sumatra Selatan. Pada proyek Jalan Tol Kapal Betung, terdapat 2 tipikal ketinggian jalan rencana yaitu top elevasi 5,6 m pada STA 44+900 - STA $46+550$ dan top elevasi $4,3 \mathrm{~m}$ pada STA 51+620 - STA 51+980 (data dapat dilihat pada lapiran 1-9). Lebar jalan rencana adalah 25,70 $\mathrm{m}$ dengan panjang jalan untuk tipikal ketinggian 5,60 m sepanjang $720 \mathrm{~m}$ dan panjang jalan untuk tipikal ketinggian
4,30 m adalah $360 \mathrm{~m}$. Untuk tipikal ketinggian 5,6 m terbagi menjadi 6 cell. dan untuk tipikal ketinggian 4,3 m terbagi menjadi 3 cell. Beban rencana adalah beban yang akan diaplikasikan di atas tanah dasar. Beban tersebut meliputi beban dari perkerasan jalan dan beban lalu lintas yaitu sebesar $50 \mathrm{kN} / \mathrm{m}^{2}$.

Data yang digunakan dalam analisa adalah data hasil uji sondir (terdapat pada lampiran 1-9), di mana dari hasil pengujian dapat diketehui kedalaman tanah lunak, kedalaman pemancangan PVD, serta dapat diketahui jenis tanah dasar pada lokasi tersebut. Properti tanah dasar yang diambil untuk analisis pada penelitian ini dipilih dari beberapa data sondir di rentang penanganan tersebut. Ada 9 data sondir yang digunakan sebagai acuan penelitian yaitu STA $45+010$, 45+060, 45+160, 46+195, 46+410, 46+460, $51+725, \quad 51+843$, dan 51+945. Tanah timbunan yang direncanakan sebagai preload pada proyek ini merupakan tanah lempung dengan berat volume $17 \mathrm{kN} / \mathrm{m}^{3}$.

Analisa yang dilakukan pada penelitian ini meliputi analisa waktu konsolidasi alami dan waktu konsolidasi dengan PVD. Dimana, PVD dikombinasikan dengan metode Preloading dan metode vakum.

\section{Konsolidasi Alami}

Analisa konsolidasi dilakukan pada Jalan Tol Kapal Betung, dimana diperoleh besarnya waktu dan penurunan konsolidasi terdapat pada Tabel 1 dan Gambar 2 sebagai berikut.

Berdasarkan Tabel 1 dan Gambar 2, terlihat bahwa pada STA $46+410$ memiliki waktu konsolidasi yang paling lama yaitu 36 tahun dengan penurunan yang paling besar yaitu $1,3 \mathrm{~m}$. Sementara itu, waktu konsolidasi tercepat terdapat pada STA $51+725$ yaitu 17 tahun dengan besar penurunan $0,35 \mathrm{~m}$.

Besarnya waktu dan penurunan konsolidasi berbeda-beda tergantung pada kedalaman tanah lunak dan permeabilitas masing-masing tanah yang dapat mempengaruhi kemampuan air dalam mengalir melalui partikel tanah. 
Tabel 1. Hasil Perhitungan Waktu Konsolidasi Alami

\begin{tabular}{cccc}
\hline STA & $\begin{array}{c}\text { Tebal } \\
\text { Tanah } \\
\text { Lunak } \\
(\mathbf{m})\end{array}$ & $\begin{array}{c}\text { Penurunan } \\
\mathbf{9 0 \%} \\
(\mathbf{m})\end{array}$ & $\begin{array}{c}\text { Waktu } \\
\text { konsoli- } \\
\text { dasi } \\
\text { alami } \\
\mathbf{9 0 \%} \\
\text { (thn) }\end{array}$ \\
\hline $\begin{array}{c}\text { 44+900 - } \\
45+020\end{array}$ & 9,6 & 0,77 & 28,37 \\
$45+020-$ & 12 & 0,99 & 22,31 \\
$45+140$ & & 0,85 & 22,33 \\
$45+140-$ & 13,8 & 1,17 & 24,08 \\
$45+260$ & & 1,32 & 35,75 \\
$46+190-$ & 11,2 & & \\
$46+310$ & & 1,23 & 34,97 \\
$46+310-$ & 15 & & \\
$46+430$ & & 0,37 & 16,46 \\
$46+430-$ & 15,6 & & 19,47 \\
$46+550$ & & 0,70 & 21,36 \\
$51+620-$ & 9,6 & 0,72 & \\
$51+740$ & & & \\
$51+740-$ & 12,4 & & \\
$51+860$ & & & \\
$51+860-$ & 13,2 & & \\
$51+962$ & & & \\
\hline
\end{tabular}

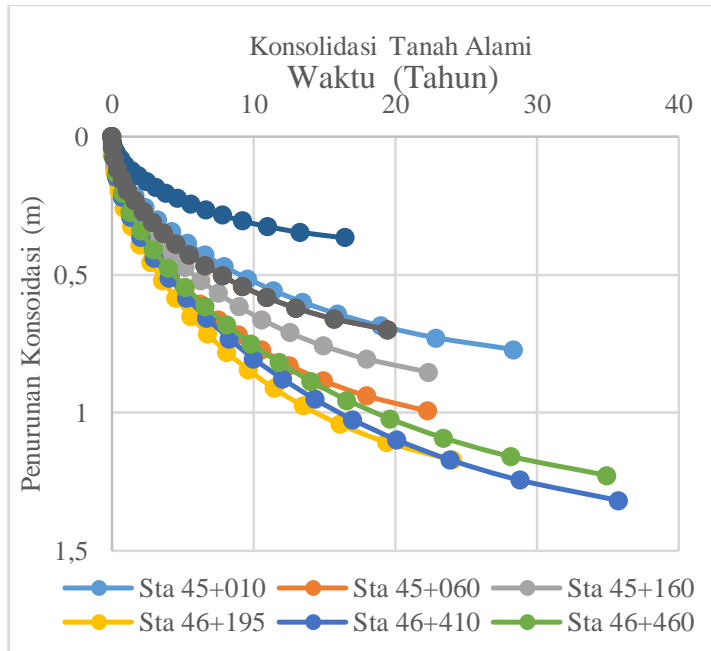

Gambar 2. Grafik Konsolidasi Tanah Alami

\section{Konsolidasi dengan Vertikal Drain}

Dalam perencanaan PVD terdapat 2 pola pemancangan PVD yaitu pola segitiga dan pola segiempat. Pola segitiga dapat digunakan pada konstruksi PVD yang dikombinasikan dengan beban Preloading, hal ini dikarenakan dengan menggunakan pola pemancangan PVD segitiga, dapat meminimalisir bidang yang tidak terdampak dari sistem PVD. Akan tetapi, pola segitiga tidak direkomendasikan untuk digunakan pada sistem PVD yang dikombinasikan dengan beban vakum. Hal ini dikarenakan jika menggunakan pola tersebut, sistem pipa pada pompa vakum sulit untuk diinstalasikan.

Di sisi lain, pola pemasangan PVD segiempat dapat digunakan baik untuk instalasi PVD dengan kombinasi Preloading maupun vakum. Oleh karena itu, pada perencanaan digunakan pola pemasangan PVD segiempat. Karena digunakan pola segiempat, maka diameter pengaruh PVD yang digunakan adalah $\mathrm{D}=1,13 \times \mathrm{S}$, dan untuk tanah yang relative homogen, nilai $\mathrm{C}_{\mathrm{h}} / \mathrm{C}_{\mathrm{v}}$ yang digunakan ialah 1-1,5 [1]. Sehingga pada perencanaan ini nilai $\mathrm{C}_{\mathrm{h}} / \mathrm{C}_{\mathrm{v}}$ yang digunakan adalah 1 dan 1,5.

Tabel 2. Hasil Perhitungan Waktu Konsolidasi PVD dengan Spasi 1 dan 1,2 dengan $\mathrm{C}_{\mathrm{h}} / \mathrm{C}_{\mathrm{v}} 1$

\begin{tabular}{|c|c|c|c|}
\hline \multirow{2}{*}{ STA } & \multirow{2}{*}{$\begin{array}{l}\text { Keda- } \\
\text { laman } \\
\text { Peman- } \\
\text { cangan } \\
\text { (m) }\end{array}$} & \multicolumn{2}{|c|}{$\begin{array}{c}\text { Waktu } \\
\text { PVD 90\% } \\
\text { (minggu) }\end{array}$} \\
\hline & & $\begin{array}{c}\text { Spacing } \\
\text { PVD } \\
1 \mathrm{~m}\end{array}$ & $\begin{array}{c}\text { Spacing } \\
\text { PVD } \\
1,2 \mathrm{~m}\end{array}$ \\
\hline $\begin{array}{c}44+900- \\
45+020\end{array}$ & 9,6 & 15 & 22 \\
\hline $\begin{array}{c}45+020- \\
45+140\end{array}$ & 12 & 8 & 11 \\
\hline $\begin{array}{c}45+140- \\
45+260\end{array}$ & 13,8 & 6 & 9 \\
\hline $\begin{array}{c}46+190- \\
46+310\end{array}$ & 11,2 & 10 & 14 \\
\hline $\begin{array}{c}46+310- \\
46+430\end{array}$ & 15 & 8 & 12 \\
\hline $\begin{array}{c}46+430- \\
46+550\end{array}$ & 15,6 & 7 & 11 \\
\hline $\begin{array}{c}51+620- \\
51+740\end{array}$ & 9,6 & 9 & 13 \\
\hline $\begin{array}{c}51+740- \\
51+860\end{array}$ & 12,4 & 6 & 9 \\
\hline $\begin{array}{c}51+860- \\
51+962\end{array}$ & 13,2 & 6 & 9 \\
\hline
\end{tabular}

Tabel 2 tersebut menunjukkan waktu konsolidasi tanah setelah dilakukan treatment dengan PVD, dimana jarak 
antar PVD yang digunakan adalah $1 \mathrm{~m}$ (Gambar 3) dan 1,2 m (Gambar 4) dengan nilai perbandingan $\mathrm{C}_{\mathrm{h}} / \mathrm{C}_{\mathrm{v}}$ adalah 1,5. Berdasarkan Tabel 1 dan Gambar 3 \& 4 tersebut terlihat bahwa dengan menggunakan jarak antar PVD $1 \mathrm{~m}$, waktu konsolidasi tanah yang paling lama pada STA 46+410 adalah 10 minggu. Di sisi lain, waktu konsolidasi PVD yang tercepat terdapat pada STA 45+160 dan STA 51+843 dengan waktu konsolidasi PVD adalah 4 minggu.

Selain itu, waktu konsolidasi tanah setelah dilakukan treatment dengan PVD dimana jarak antar PVD yang digunakan adalah 1,2 $\mathrm{m}$ dengan nilai perbandingan $\mathrm{C}_{\mathrm{h}} / \mathrm{C}_{\mathrm{v}}$ adalah 1,5. Berdasarkan grafik tersebut terlihat bahwa dengan menggunakan PVD, waktu konsolidasi tanah yang paling lama pada STA 46+410 adalah 15 minggu. Di sisi lain, waktu konsolidasi PVD yang tercepat terdapat pada STA $45+160$ dan STA 51+843 dengan waktu konsolidasi PVD adalah 6 minggu.

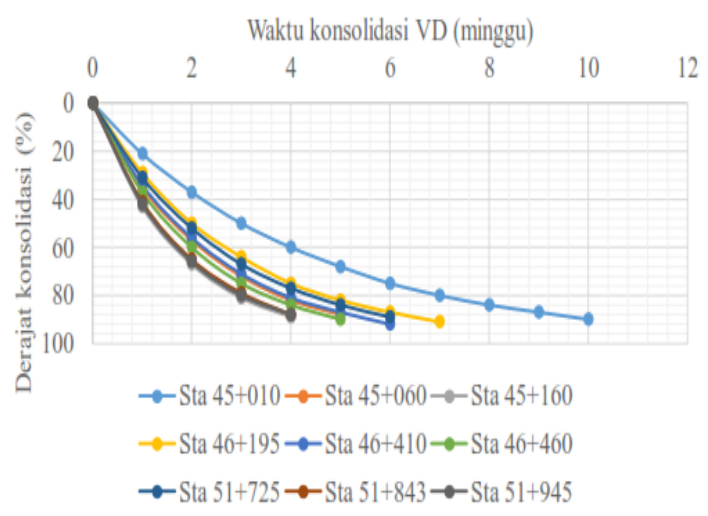

Gambar 3. Grafik Hubungan antara Waktu Konsolidasi dengan Derajat Konsolidasi PVD Spasi 1 dengan $\mathrm{Ch} / \mathrm{Cv}$ 1,5

Jika menggunakan nilai $\mathrm{C}_{\mathrm{h}} / \mathrm{C}_{\mathrm{v}} 1$, maka akan menghasilkan waktu PVD yang semakin lama. Sementara itu, jika menggunakan $\mathrm{C}_{\mathrm{h}} / \mathrm{C}_{\mathrm{v}} 1,5$, maka akan menghasilkan waktu PVD yang lebih cepat. Oleh karena itu digunakan nilai $\mathrm{C}_{\mathrm{h}} / \mathrm{C}_{\mathrm{v}}$ 1. Hal ini dikarenakan semakin kecil nilai $\mathrm{C}_{\mathrm{h}} / \mathrm{C}_{\mathrm{v}}$ akan menghasilkan waktu penurunan yang lebih lama. Sehingga perencanaan ini telah mempertimbangkan kemungkinan terburuk apabila terjadi kendala pada saat proses konsolidasi berlangsung.

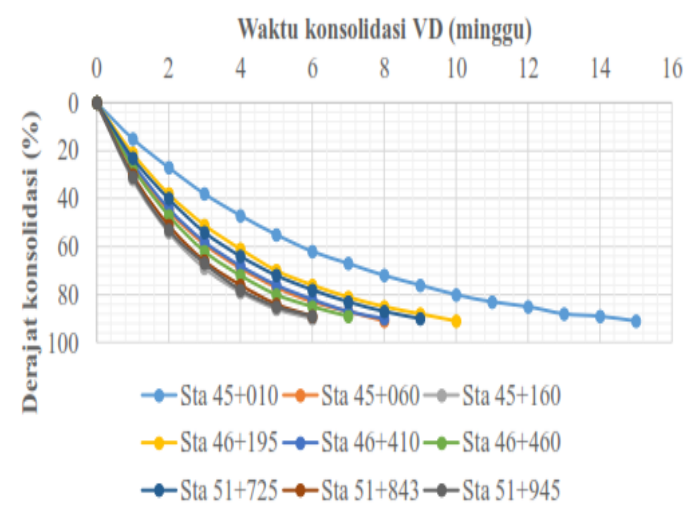

Gambar 4. Grafik Hubungan antara Waktu Konsolidasi dengan Derajat Konsolidasi PVD Spasi 1,2 dengan $\mathrm{Ch} / \mathrm{Cv}$ 1,5

Berdasarkan analisa tersebut dapat disimpulkan bahwa dengan spasi PVD 1 m menghasilkan waktu PVD yang lebih singkat jika dibandingkan dengan spasi PVD 1,2 m. Hal ini dikarenakan semakin dekat jarak antar PVD maka cakupan area yang dapat ditangani oleh PVD lebih maksimal, akan tetapi jarak PVD minimal $1 \mathrm{~m}$.

Tabel 3 tersebut menunjukkan waktu konsolidasi tanah setelah dilakukan treatment dengan PVD, dimana jarak antar PVD yang digunakan adalah $1 \mathrm{~m}$ dan 1,2 $\mathrm{m}$ dengan nilai perbandingan $\mathrm{C}_{\mathrm{h}} / \mathrm{C}_{\mathrm{v}}$ adalah 1,5. Berdasarkan tabel tersebut terlihat bahwa dengan menggunakan jarak antar PVD $1 \mathrm{~m}$, waktu konsolidasi tanah yang paling lama pada STA $46+410$ adalah 10 minggu. Di sisi lain, waktu konsolidasi PVD yang tercepat terdapat pada STA 45+160 dan STA 51+843 dengan waktu konsolidasi PVD adalah 4 minggu. 
Tabel 3. Hasil Perhitungan Waktu Konsolidasi PVD Spasi 1 dan 1,2 dengan $\mathrm{C}_{\mathrm{h}} / \mathrm{C}_{\mathrm{v}} 1,5$

\begin{tabular}{|c|c|c|c|}
\hline \multirow{2}{*}{ STA } & \multirow{2}{*}{$\begin{array}{l}\text { Kedala- } \\
\text { man } \\
\text { Peman- } \\
\text { cangan } \\
(\mathrm{m})\end{array}$} & \multicolumn{2}{|c|}{$\begin{array}{c}\text { Waktu } \\
\text { PVD 90\% } \\
\text { (minggu) }\end{array}$} \\
\hline & & $\begin{array}{c}\text { Spacing } \\
\text { PVD } \\
1 \mathrm{~m}\end{array}$ & $\begin{array}{c}\text { Spacing } \\
\text { PVD } \\
1,2 \mathrm{~m}\end{array}$ \\
\hline $\begin{array}{c}44+900- \\
45+020\end{array}$ & 9,6 & 10 & 15 \\
\hline $\begin{array}{c}45+020- \\
45+140\end{array}$ & 12 & 5 & 8 \\
\hline $\begin{array}{c}45+140- \\
45+260\end{array}$ & 13,8 & 4 & 6 \\
\hline $\begin{array}{c}46+190- \\
46+310\end{array}$ & 11,2 & 7 & 10 \\
\hline $\begin{array}{c}46+310- \\
46+430\end{array}$ & 15 & 6 & 8 \\
\hline $\begin{array}{c}46+430- \\
46+550\end{array}$ & 15,6 & 5 & 7 \\
\hline $\begin{array}{c}51+620- \\
51+740\end{array}$ & 9,6 & 6 & 9 \\
\hline $\begin{array}{c}51+740- \\
51+860\end{array}$ & 12,4 & 4 & 6 \\
\hline $\begin{array}{c}51+860- \\
51+962\end{array}$ & 13,2 & 4 & 6 \\
\hline
\end{tabular}

Selain itu, waktu konsolidasi tanah setelah dilakukan treatment dengan PVD dimana jarak antar PVD yang digunakan adalah 1,2 $\mathrm{m}$ dengan nilai perbandingan $\mathrm{C}_{\mathrm{h}} / \mathrm{C}_{\mathrm{v}}$ adalah 1,5. Berdasarkan grafik tersebut terlihat bahwa dengan menggunakan PVD, waktu konsolidasi tanah yang paling lama pada STA 46+410 adalah 15 minggu. Di sisi lain, waktu konsolidasi PVD yang tercepat terdapat pada STA 45+160 dan STA 51+843 dengan waktu konsolidasi PVD adalah 6 minggu.

Besar spasi sangatlah berpengaruh karena semakin besar spasi maka waktu penurunan tanah semakin lama [3]. Pernyataan ini sesuai dengan hasil analisa yang telah dilakukan. Hal ini dapat terjadi karena semakin dekat jarak antar PVD maka cakupan area yang dapat ditangani oleh PVD lebih maksimal, akan tetapi jarak PVD minimal $1 \mathrm{~m}$.

PVD membantu air pori keluar secara vertical, sementara itu air pori yang sudah sampai di permukaan tanah perlu dialirkan kembali secara horizontal sehingga pada akhirnya sampai kepada saluran drainase. Penyaluran air secara horizontal dapat menggunakan media pasir (sandblanket) maupun PHD (Prefabricated Horizontal Drain). Gambar sistem PVD terdapat pada Gambar 5 adalah sebagai berikut.

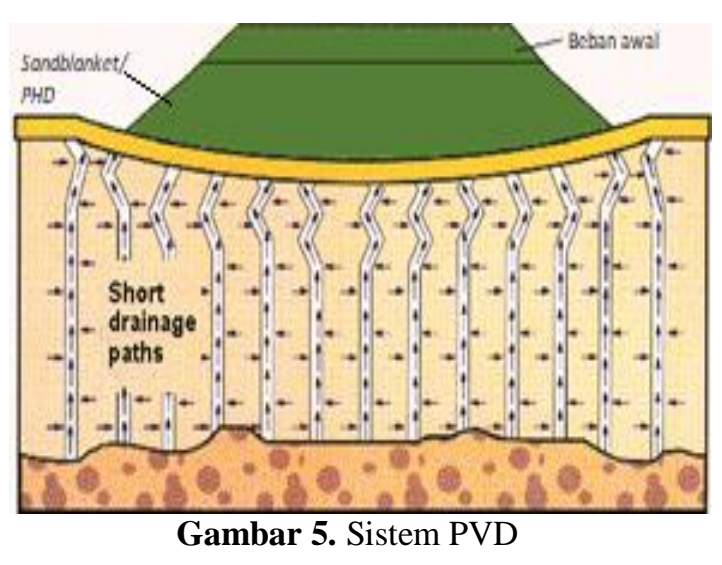

\section{Stabilitas Timbunan}

Instalasi PVD dikombinasikan dengan metode Preloading ataupun metode vakum. Metode ini bertujuan sebagai beban di atas tanah dasar yang dapat membantu untuk menekan laju air pori keluar ke dalam tanah. Dalam pengaplikasian metode tersebut diperlukan konstruksi timbunan. Penimbunan dilakukan secara bertahap, hal ini dikarenakan tanah dasar tidak mampu untuk mendukung tanah timbunan yang terlalu tinggi di atasnya. Oleh karena itu, dilakukan analisis stabilitas timbunan. Hal ini dimaksudkan supaya timbunan stabil saat dilakukan konstruksi.

Suatu konstruksi dapat dikatakan stabil jika memiliki nilai factor keamanan minimum sebesar 1,35 [7]. Perhitungan stabilitas timbunan menggunakan program Plaxis. PLAXIS adalah program komputer yang dapat digunakan untuk menganalisa deformasi, aliran air tanah, dan konsolidasi [6]. Parameter tanah yang digunakan berdasarkan korelasi dari hasil uji sondir dengan peningkatan nilai 
kuat geser berdasarkan hasil perhitungan. Hasil analisanya terdapat pada Tabel 4 sebagai berikut.

Tabel 4. Rekapitulasi waktu konstruksi dan Faktor Keamanan

\begin{tabular}{|c|c|c|c|c|}
\hline \multirow{2}{*}{ STA } & \multicolumn{2}{|c|}{$\begin{array}{c}\text { Waktu } \\
\text { Konstruksi }\end{array}$} & \multicolumn{2}{|c|}{ FK Konstruksi } \\
\hline & $\begin{array}{c}\text { Preloa- } \\
\text { Ding }\end{array}$ & Vakum & $\begin{array}{l}\text { Preloa- } \\
\text { ding }\end{array}$ & Vakum \\
\hline $\begin{array}{c}44+900- \\
45+020\end{array}$ & 16 & 10 & 1,63 & 1,97 \\
\hline $\begin{array}{c}45+020- \\
45+140\end{array}$ & 16 & 10 & 1,59 & 1,89 \\
\hline $\begin{array}{c}45+140- \\
45+260\end{array}$ & 16 & 10 & 1,41 & 1,94 \\
\hline $\begin{array}{c}46+190- \\
46+310\end{array}$ & 56 & 10 & 1,45 & 1,79 \\
\hline $\begin{array}{c}46+310- \\
46+430\end{array}$ & 63 & 12 & 1,36 & 1,64 \\
\hline $\begin{array}{c}46+430- \\
46+550\end{array}$ & 56 & 10 & 1,38 & 1,57 \\
\hline $\begin{array}{c}51+620- \\
51+740\end{array}$ & 126 & 6 & 1,36 & 1,38 \\
\hline $\begin{array}{c}51+740- \\
51+860\end{array}$ & 14 & 8 & 1,63 & 2,29 \\
\hline $\begin{array}{c}51+860- \\
51+962\end{array}$ & 28 & 8 & 1,36 & 1,96 \\
\hline
\end{tabular}

Berdasarkan analisa yang telah dilakukan dapat disimpulkan bahwa dengan menggunakan metode Preloading diperlukan waktu tunggu konstruksi timbunan yang lebih lama jika dibandingkan dengan metode vakum.

Setelah konstruksi selesai, dilakukan stripping atau pemotongan Preloading yang melebihi tinggi timbunan rencana. Selanjutnya setelah dilakukan stripping pasca konsolidasi, konstruksi jalan dapat dibangun sesuai dengan perkerasan rencana. Berikut adalah hasil analisa stabilitas timbunan setelah dilakukan stripping dan jalan tol difungsikan sebagaimana mestinya, nilai factor keamanan yang diperolah terdapat pada Tabel 5 sebagai berikut.
Tabel 5. Rekapitulasi Faktor Keamanan Pasca Konsolidasi

\begin{tabular}{ccc}
\hline STA & Metode PVD & $\begin{array}{c}\text { Faktor } \\
\text { Keamanan }\end{array}$ \\
\hline $44+900-$ & Preloading & 2,11 \\
$45+020$ & Vakum & 2,14 \\
$45+020-$ & Preloading & 2,03 \\
$45+140$ & Vakum & 1,93 \\
$45+140-$ & Preloading & 2,10 \\
$45+260$ & Vakum & 2,14 \\
$46+190-$ & Preloading & 1,54 \\
$46+310$ & Vakum & 1,91 \\
$46+310-$ & Preloading & 1,92 \\
$46+430$ & Vakum & 1,89 \\
$46+430-$ & Preloading & 1,99 \\
$46+550$ & Vakum & 1,90 \\
$51+620-$ & Preloading & 1,74 \\
$51+740$ & Vakum & 1,72 \\
$51+740-$ & Preloading & 2,19 \\
$51+860$ & Vakum & 2,25 \\
$51+860-$ & Preloading & 2,20 \\
$51+962$ & Vakum & 2,30 \\
\hline
\end{tabular}

Berdasarkan Tabel 5 diperoleh nilai faktor keamanan konstruksi timbunan baik dengan metode Preloading maupun metode vakum lebih besar dari nilai faktor keamanan minimum 1,35.

Pada metode Preloading diperlukan waktu tunggu untuk meningkatkan daya dukung tanah dasar sampai dapat diaplikasikan beban timbunan yang lebih tinggi di atasnya. Selain itu factor keamanan konstruksi yang diperoleh dengan metode vakum lebih besar jika dibandingkan dengan metode Preloading. Hal ini dikarenakan dengan metode vakum, tekanan dengan jumlah yang besar dapat langsung diaplikasikan di atas tanah dasar sehingga menyebabkan peningkatan daya dukung tanah dasar yang langsung signifikan. Sehingga dapat disimpulkan bahwa metode vakum memiliki waktu tunggu yang lebih cepat dan memiliki factor keamanan konstruksi yang lebih besar jika dibandingkan dengan metode Preloading.

Analisa stabilitas dilakukan juga pada kondisi setelah konsolidasi berlangsung. 
Berdasarkan analisa diperoleh nilai factor keamanan yang sudah lebh besar dari nilai factor keamanan minimum yaitu 1,35 . Sehingga dapat disimpulkan bahwa setelah konsolidasi berlangsung, tanah telah memiliki daya dukung yang mencukupi dan mampu untuk menahan beban timbunan, beban perkerasan, dan beban kendaraan diatasnya. Maka dapat disimpulkan bahwa setelah dilakukan treatment PVD pada tanah dasar, konstruksi timbunan stabil dan tanah dasar telah memiliki daya dukung yang mencukupi.

\section{Kesimpulan}

Berdasarkan penelitian Analisa Konsolidasi pada Tanah Lempung Lunak dengan Menggunakan Metode Prefabricated Vertical Drain (PVD), diperoleh kesimpulan sebagai berikut.

1. Prefabricated vertical drain (PVD) berfungsi sebagai saluran untuk mengeluakan air pori tanah, dengan adanya PVD maka air pori tanah dapat mudah keluar ke permukaan tanah. PVD harus dikombinasikan dengan beban baik berupa tanah timbunan (Preloading) maupun kombinasi Preloading dan tekanan vakum. Dengan adanya PVD, maka waktu yang dibutuhkan untuk konsolidasi tanah lebih cepat jika dibandingkan dengan waktu konsolidasi alami tanah.

2. Jika menggunakan metode Preloading, diperlukan waktu konstruksi timbunan bertahap agar memperoleh nilai daya dukung tanah dasar yang mencukupi untuk dapat menopang beban timbunan di atasnya. Berdasarkan analisa, waktu konstruksi yang dibutuhkan untuk timbunan Preloading antara 14 hari sampai 126 hari. Sementara itu jika menggunakan metode vakum yang dikombinasikan beban Preloading, diperlukan waktu konstruksi antara 6 hari sampai 14 hari. Perbedaan waktu konstruksi disebabkan karena pada metode vakum, tekanan vakum dapat langsung diaplikasikan di atas tanah dasar yang lunak, di mana tekanan tersebut dapat meningkatkan daya dukung tanah yang sangat besar karena tekanan vakum sama saja dengan pengaplikasian beban timbunan setinggi $\pm 4 \mathrm{~m}$ tanah timbunan.

3. Nilai faktor keamanan konstruksi tanah dasar dan timbunan setelah dilakukan treatment PVD Preloading adalah sebesar 1,36 - 1,63 dengan ketinggian timbunan Preloading 7,61 - 9,86 m. Sementara itu jika menggunakan metode PVD vakum, diperoleh nilai factor keamanan sebesar 1,38 - 2,29 dengan tinggi timbunan Preloading 4,67 - 6,92 m. Sehingga dapat disimpulkan bahwa metode vakum dapat meningkatkan nilai faktor keamanan yang lebih signifikan jika dibandingkan dengan metode Preloading. Hal ini dikarenakan tekanan vakum dapat meningkatkan kekuatan tanah dasar lebih cepat jika dibandingkan dengan tekanan yang diakibatkan oleh beban Preloading tanah. Selain itu dengan menggunakan metode vakum, volume tanah timbunan yang diperlukan lebih sedikit jika dibandingkan dengan metode Preloading. Hal ini dikarenakan tekanan vakum dapat menggantikan \pm $4 \mathrm{~m}$ tanah timbunan.

\section{Ucapan Terima Kasih}

Terima kasih kepada Ibu Sri Wulandari yang telah membimbing saya dan mengarahkan saya dalam proses penyusunan penelitian ini, sehingga penelitian ini dapat saya selesaikan dengan baik. 


\section{Daftar Pustaka}

[1] Aspara, W. A. N., \& Fitriani, E. N. (2016). Pengaruh Jarak Dan Pola Prefabricated Vertical Drain (Pvd) Pada Perbaikan Tanah Lempung Lunak = Effect of Distance and Pattern of Prefabricated Vertical Drain for Improvement of Soft Clay Soil. Majalah Ilmiah Pengkajian Industri, $\quad 10(1), \quad 41$. https://doi.org/10.29122/mipi.v10i1 .102

[2] Ba, S., Beu, C. M. L., \& Falck, A. S. (2015). Studi Penurunan Tanah Di Atas Tanah Lunak (Studi Kasus Jalan Nasional Tikke - Baras, Sulawesi Barat). 1-9.

[3] Hamida, H. et al. (2014). Pengaruh Spasi Pada Performa Prefabricated Vertical Drain (Pvd) Dalam Perbaikan Tanah Lunak. Pengaruh Spasi Pada Performa Prefabricated Vertical Drain (Pvd) Dalam Perbaikan Tanah Lunak, 1(2), 1-8.

[4] Kuswanda, W. P. (2015). Problematika Pembangunan Infrastruktur Pada Tanah Lempung Lunak Dan Alternatif Metoda Penanganannya. 270-288.

[5] Ohoimas, M. Y., \& Hamdhan, I. N. (2014). Analisis Konsolidasi dengan Menggunakan Metode Preloading dan Vertical Drain pada Areal Reklamasi Proyek Pengembangan Pelabuhan Belawan tahap II. Jurnal Online Institut Teknologi Nasional, (x), 1-11.

[6] Rivanga, N. U., \& Hamdhan, I. N. (2018). Analisis Vacuum Consolidation pada Perbaikan Tanah Lempung Lunak dengan Model Axisymmetric. 4(1), 68-79.

[7] SNI 8460-2017. (2017). Persyaratan Perancangan Geoteknik. 324.

[8] Widoanindyawati, V., Prabandiyani, S., Wardani, R., \& Partono, W. (2016). Studi Kasus Konstruksi Timbunan Apron
Bandara Ahmad Yani Semarang. (November), 1-11. 


\section{LAMPIRAN 1}

DIGITAL SONDIR HYDRAULIC 10 TONS

SO 210 Dutch Cone Penetrometer 10 Ton Capacity Digital Data Reading

Location : $(45+010)$

Date $\quad: 16$ Mei 17

\begin{tabular}{|c|c|c|c|c|c|c|c|c|}
\hline Kedalaman & qc & JH & $\mathbf{H P}$ & HP $(2 \times C)$ & JHP & HS (Cx0,1) & $\mathrm{fr}$ & SOIL BEHAVIOR \\
\hline$(\mathbf{m})$ & $\mathrm{Kg} / \mathrm{cm}^{2}$ & $\mathrm{Kg} / \mathrm{cm}^{2}$ & $\mathrm{Kg} / \mathrm{cm}^{2}$ & $\mathrm{Kg} / \mathrm{cm}^{2}$ & $\mathrm{Kg} / \mathrm{cm}$ & $\mathrm{Kg} / \mathrm{cm}$ & $(\%)$ & (SCHMERTMANN, 1978) \\
\hline & $\mathrm{A}$ & $\mathrm{B}$ & $\mathrm{C}$ & $\mathrm{D}$ & $\mathrm{E}$ & $\mathrm{F}$ & $\mathrm{G}=\mathrm{F} / \mathrm{A}$ & \\
\hline $\mathbf{0 , 0 0}$ & 0 & 0 & 0 & 0 & 0 & 0 & 0 & \multirow{6}{*}{ TIMBUNAN } \\
\hline 0,20 & 24 & 35 & 11 & 22 & 11 & 1,1 & 4,6 & \\
\hline 0,40 & 14 & 27 & 13 & 26 & 24 & 1,3 & 9,3 & \\
\hline 0,60 & 13 & 26 & 13 & 26 & 37 & 1,3 & 10,0 & \\
\hline 0,80 & 10 & 19 & 9 & 18 & 46 & 0,9 & 9,0 & \\
\hline 1,00 & 10 & 12 & 2 & 4 & 48 & 0,2 & 2,0 & \\
\hline 1,20 & 4 & 9 & 5 & 10 & 53 & 0,5 & 12,5 & \multirow{39}{*}{$\begin{array}{c}\text { ORGANIC CLAYS \& MIXED } \\
\text { SOILS }\end{array}$} \\
\hline 1,40 & 5 & 13 & 8 & 16 & 61 & 0,8 & 16,0 & \\
\hline 1,60 & 6 & 11 & 5 & 10 & 66 & 0,5 & 8,3 & \\
\hline 1,80 & 5 & 10 & 5 & 10 & 71 & 0,5 & 10,0 & \\
\hline 2,00 & 4 & 10 & 6 & 12 & 77 & 0,6 & 15,0 & \\
\hline 2,20 & 5 & 12 & 7 & 14 & 84 & 0,7 & 14,0 & \\
\hline 2,40 & 6 & 10 & 4 & 8 & 88 & 0,4 & 6,7 & \\
\hline 2,60 & 6 & 12 & 6 & 12 & 94 & 0,6 & 10,0 & \\
\hline 2,80 & 5 & 13 & 8 & 16 & 102 & 0,8 & 16,0 & \\
\hline 3,00 & 6 & 12 & 6 & 12 & 108 & 0,6 & 10,0 & \\
\hline 3,20 & 6 & 13 & 7 & 14 & 115 & 0,7 & 11,7 & \\
\hline 3,40 & 7 & 14 & 7 & 14 & 122 & 0,7 & 10,0 & \\
\hline 3,60 & 6 & 11 & 5 & 10 & 127 & 0,5 & 8,3 & \\
\hline 3,80 & 7 & 14 & 7 & 14 & 134 & 0,7 & 10,0 & \\
\hline 4,00 & 8 & 14 & 6 & 12 & 140 & 0,6 & 7,5 & \\
\hline 4,20 & 8 & 15 & 7 & 14 & 147 & 0,7 & 8,8 & \\
\hline 4,40 & 9 & 16 & 7 & 14 & 154 & 0,7 & 7,8 & \\
\hline 4,60 & 7 & 14 & 7 & 14 & 161 & 0,7 & 10,0 & \\
\hline 4,80 & 7 & 16 & 9 & 18 & 170 & 0,9 & 12,9 & \\
\hline 5,00 & 7 & 16 & 9 & 18 & 179 & 0,9 & 12,9 & \\
\hline 5,20 & 8 & 19 & 11 & 22 & 190 & 1,1 & 13,8 & \\
\hline 5,40 & 9 & 17 & 8 & 16 & 198 & 0,8 & 8,9 & \\
\hline 5,60 & 8 & 19 & 11 & 22 & 209 & 1,1 & 13,8 & \\
\hline 5,80 & 7 & 18 & 11 & 22 & 220 & 1,1 & 15,7 & \\
\hline 6,00 & 9 & 19 & 10 & 20 & 230 & 1 & 11,1 & \\
\hline 6,20 & 9 & 18 & 9 & 18 & 239 & 0,9 & 10,0 & \\
\hline 6,40 & 8 & 17 & 9 & 18 & 248 & 0,9 & 11,3 & \\
\hline 6,60 & 8 & 18 & 10 & 20 & 258 & 1 & 12,5 & \\
\hline 6,80 & 8 & 19 & 11 & 22 & 269 & 1,1 & 13,8 & \\
\hline 7,00 & 8 & 17 & 9 & 18 & 278 & 0,9 & 11,3 & \\
\hline 7,20 & 7 & 11 & 4 & 8 & 282 & 0,4 & 5,7 & \\
\hline 7,40 & 7 & 16 & 9 & 18 & 291 & 0,9 & 12,9 & \\
\hline 7,60 & 7 & 18 & 11 & 22 & 302 & 1,1 & 15,7 & \\
\hline 7,80 & 7 & 16 & 9 & 18 & 311 & 0,9 & 12,9 & \\
\hline 8,00 & 8 & 17 & 9 & 18 & 320 & 0,9 & 11,3 & \\
\hline 8,20 & 8 & 16 & 8 & 16 & 328 & 0,8 & 10,0 & \\
\hline 8,40 & 9 & 18 & 9 & 18 & 337 & 0,9 & 10,0 & \\
\hline 8,60 & 8 & 16 & 8 & 16 & 345 & 0,8 & 10,0 & \\
\hline 8,80 & 9 & 17 & 8 & 16 & 353 & 0,8 & 8,9 & \\
\hline 9,00 & 9 & 12 & 3 & 6 & 356 & 0,3 & 3,3 & SILTY CLAYS \\
\hline 9,20 & 11 & 19 & 8 & 16 & 364 & 0,8 & 7,3 & \multirow{3}{*}{$\begin{array}{c}\text { ORGANIC CLAYS \& MIXED } \\
\text { SOILS }\end{array}$} \\
\hline 9,40 & 10 & 20 & 10 & 20 & 374 & 1 & 10,0 & \\
\hline 9,60 & 9 & 18 & 9 & 18 & 383 & 0,9 & 10,0 & \\
\hline 9,80 & 15 & 21 & 6 & 12 & 389 & 0,6 & 4,0 & CLAY, Stiff \\
\hline 10,00 & 10 & 21 & 11 & 22 & 400 & 1,1 & 11,0 & ORGANIC CLAYS \\
\hline
\end{tabular}

